\title{
Effect of Admixtures on Durability Characteristics of Fly Ash Alkali-activated Material
}

\author{
Lukáš Procházka ${ }^{\mathrm{a} *}$, Jana Boháčová ${ }^{\mathrm{a}}$ \\ ${ }^{a}$ Department of Building Materials and Diagnostics of Structures, Faculty of Civil Engineering, VŠB-TUO, Ludvika Podéště 1875/17, 708 \\ Oo Ostrava-Poruba, Czech Republic
}

\begin{abstract}
This paper deals with the possibility of partial replacement of blast furnace slag with fly ash and fly ash after denitrification by SNCR method in alkali-activated materials based on granulated blast furnace slag. The aim of this paper is to verify the effect of fly ash on properties of alkali-activated materials based on blast furnace granulated slag. Frost resistance and resistance to aggressive environments, represented by demineralized water were tested. The reference mixture was based on blast furnace granulated slag activated by sodium water glass with silicate modulus of 2 . Mixtures with an ash content of 10,20 , and $30 \%$ were then compared with the reference mixture. The influence of the denitrification process on fly ash and its use in mixed alkali activated materials was also compared. As a part of the experiment, alkali-activated pastes were also prepared. Infrared spectroscopy with Furier transformation was subsequently determined on these pastes. The reference mixture achieved the highest compressive strength in the experiment and the strength decreased with increasing amount of fly ash. In terms of flexural strength, the highest values were reached for mixtures with $10 \%$ slag replacement by fly ash. In the case of frost resistance, the significant increase of flexural strength, which was $50 \%$ for the reference mixture, is particularly interesting. For compressive strength, the frost resistance coefficient ranged from 0.95 to 1.00 . In the case of resistance to aggressive environments, no differences were observed in the compressive strength, on the other hand, flexural strength decrease of up to $20 \%$ was detected for 10 and 20 percent replacement of slag with fly ash that did not undergo denitrification. Monitored properties did not show any negative effect of the denitrification process on fly ash properties. Infrared spectroscopy identified the main hydration product in the region of $945 \mathrm{~cm}^{-1}$ which is a C-(A)-S-H gel and in combined mixtures with fly ash also N-A-S-H gel.
\end{abstract}

\section{Keywords:}

Fly Ash;

Denitrification

Blast Furnace Slag;

Alkali-activated Material;

Frost Resistance.

Article History:

$\begin{array}{llll}\text { Received: } & 13 & \text { August } & 2020 \\ \text { Accepted: } & 17 & \text { November } & 2020 \\ \text { Published: } & 01 & \text { December } & 2020\end{array}$

\section{1- Introduction}

This paper deals with the possibility of using fly ash, including fly ash after denitrification by the SNCR method, as an additive to alkali-activated materials based on finely ground granulated blast furnace slag activated by sodium water glass with silicate modulus of 2 . The effect of fly ash on strength characteristics, as well as on the frost resistance and on resistance to demineralized water was determined.

\section{1-1-Mixed Alkali-activated Materials}

Various precursors are used for alkaline activation, such as finely ground blast furnace granulated slag, fly ash, metakaolin and others. Each material has its advantages and disadvantages. For example, blast furnace granulated slag rapidly solidifies and achieves high strengths in the initial stages of maturation, but it also has the possibility of high shrinkage cracking. Therefore, the possibilities of reducing its disadvantages, including the use of mixed binders and fibers, are being explored. These efforts focus primarily on composites, where the binder and activator are dosed separately [1].

\footnotetext{
* CONTACT: Lukas.prochazka@vsb.cz

DOI: http://dx.doi.org/10.28991/esj-2020-01247
}

(C) 2020 by the authors. Licensee ESJ, Italy. This is an open access article under the terms and conditions of the Creative Commons Attribution (CC-BY) license (https://creativecommons.org/licenses/by/4.0/). 
For mixed alkali activated materials, the addition of fly ash to the slag will increase the alumina and silica content without increase of calcium content [2]. This addition affects the mechanism and rate of gel formation. In the case of slag alkali activation by the silicate solution, the gel of type C-A-S-H dominates, and in the case of fly ash alkali activation by the silicate solution, N-A-S-H is formed [2-7]. The combination of blast furnace slag and fly ash produces these products simultaneously if the amount of fly ash does not exceed $75 \%$. If the slag content is about $50 \%$ or less, a hybrid gel in the form of $\mathrm{N}-(\mathrm{C})-\mathrm{A}-\mathrm{S}-\mathrm{H}$ is formed, because part of the dissolved Ca is incorporated into the structure of the N-A-S-gel of type $\mathrm{H}$, which is produced by the fly ash activation. Due to slower reactions in mixtures with lower content of blast furnace slag, cross-linked products are formed and denser microstructure. Using blast furnace slag and fly ash to form a common binder, will result in the formation of large amounts of tetracoordinated $\mathrm{Al}$ charge balanced by $\mathrm{Na}$ and binder gel in the hydrated $\mathrm{Na}_{2} \mathrm{O}-\mathrm{CaO}-\mathrm{Al}_{2} \mathrm{O}_{3}-\mathrm{SiO}_{2}$ system. Final products depend on various factors, such as type and concentration of the activator, the amount of slag and fly ash. Alkaline activation of blast furnace slag and fly ash and dissolution of these products may lead to higher crosslinking of these C-A-S-H and $\mathrm{N}-\mathrm{A}-\mathrm{S}-\mathrm{H}$ hydrating gels. Substitution of aluminum depends on its availability in slag or fly ash, for a mixture of slag and fly ash at a ratio of $1: 1$, a silicate modulus of 1.0-1.5 appears to be suitable, leading to the formation of these products (C-S-H and N-A-S-H) simultaneously [2].

When using mixed systems of blast furnace granulated slag and fly ash, the reaction rate increases with increasing amount of slag and with a higher dose of activator, which can complicate workability and causes a rapid change of consistency. A higher amount of fly ash prolongs the setting time and reduces the modulus of elasticity and compressive strength. At the same time, these mixtures achieve better homogeneity and the formation of microcracks is reduced. The development of short-term strength is mainly associated with the reactions of blast furnace granulated slag, while the reactions of fly ash are manifested in longer-term strength [8].

Ye (2018) and Ye et al. (2019) [9, 10] state that in addition to the main hydration product in alkali-activated slags in the form of a C-(A)-S H gel, phases of the hydrotalcite type are also formed, regardless of the chemical composition and source of reactants. These phases are bilayer hydroxides based on $\mathrm{Mg}$ - $\mathrm{Al}$. Hydrotalcite plays an important role especially in the chemical resistance of alkali-activated materials, such as chloride penetration resistance, resistance to carbon dioxide penetration and resistance to sulphates $[9,10]$.

Studies indicate that the hydrotalcite phases may be in the form of either plate or lath precipitates or may be present on a very fine scale in the internal structure of the C-A-S-H gel [9].

\section{2- Experimental Part}

The basic physical-mechanical properties of alkali-activated materials based on blast-furnace granulated slag with the replacement of a part of the slag with fly ash in the proportions of 10, 20 and 30\% were studied. This proportion was chosen according to Vlček (2008) study [11], where better results were achieved when replacing $20 \%$ slag with fly ash.

\section{- Silica fly ash}

Ashes from the Ostrava - Třebovice power plant were used. Silica fly ashes before (FA) and after denitrification by SNCR method (FAD) were used. Ground fly ash with a specific surface area of $500 \mathrm{~m}^{2} / \mathrm{kg}$ was used for the experiment. The content of ammonia released from the aqueous extract is $22.8 \mathrm{mg} / \mathrm{kg}$. The oxides are given in Table 1 .

Table 1. Percentage of oxides in fly ash.

\begin{tabular}{ccc}
\hline Oxide & FAD [\%] & FA [\%] \\
\hline $\mathrm{SiO}_{2}$ & 56.55 & 54.56 \\
$\mathbf{A l}_{2} \mathbf{O}_{3}$ & 28.86 & 31.93 \\
$\mathrm{Fe}_{2} \mathbf{O}_{3}$ & 7.85 & 7.85 \\
$\mathbf{C a O}$ & 3.94 & 4.02 \\
$\mathbf{S O}_{3}$ & 0.56 & 0.77 \\
$\mathbf{K}_{2} \mathbf{O}$ & 2.45 & 2.59 \\
$\mathbf{M g O}$ & 1.02 & 0.84 \\
\hline
\end{tabular}

\section{- Blast furnace granulated slag}

Finely ground granulated blast furnace slag (BFS) of Kotouč Štramberk, LLC. SMŠ 400, with a specific surface area of $400 \mathrm{~m}^{2} / \mathrm{kg}$ was used for the experiment. This slag has latent hydraulic properties. The percentages of the oxides obtained by measurement on a fluorescence spectrometer are given in Table 2 [12]. 
Table 2. Percentage of oxides in BFS.

\begin{tabular}{cc}
\hline \multicolumn{2}{c}{ BFS } \\
\hline Oxide & Content [\%] \\
\hline $\mathbf{C a O}$ & 40.0 \\
$\mathrm{SiO}_{2}$ & 39.9 \\
$\mathbf{A l}_{\mathbf{2}} \mathbf{O}_{3}$ & 6.9 \\
$\mathrm{MgO}$ & 8.9 \\
$\mathbf{S O}_{3}$ & 0.6 \\
$\mathbf{F}_{\mathbf{2}} \mathbf{O}_{3}$ & 0.4 \\
\hline
\end{tabular}

- Activator - Sodium water glass (SWG)

Alkaline substances that introduce into the system the alkaline environment are necessary to start the hydration processes of blast furnace slag. In the experiment, treated sodium water glass was used as the alkaline activator. It is a sodium silicate solution. For this water glass, the silicate modulus was adjusted to a value 2 with $50 \%$ sodium hydroxide solution [13].

\section{- Standardized sand}

Standardized sand CEN, due to ČSN EN 196-1 was used as a filler in the experiment. It is natural quartz sand, which consists of rounded particles and the silica content is min. $98 \%$, fraction $0 / 2 \mathrm{~mm}$ and moisture content less than $0.2 \%[14]$.

\section{2-1-Preparation and Testing}

- Preparation and testing of samples

During the experiment, samples were prepared (beams 40x40x160 mm) according to cement standards, as well as placement and subsequent testing was carried out according to cement standards [14-17].

- Determination of amorphous phase content in fly ash

The potassium hydroxide-soluble amorphous phase was determined in the assay. The ash test portion was boiled in 4M potassium hydroxide solution for 3 minutes, then the solution was filtered through filter paper. The filtered solution was neutralized with hydrochloric acid, whereby is the amorphous content of the ash precipitated by the reaction. This solution was again filtered through filter paper. The precipitate collected on the filter paper was annealed at $1000^{\circ} \mathrm{C}$. On the annealed portion, the chemical composition was determined using a spectrometer [18].

\section{- Mixture}

Previously tested mixture was used as reference mixture in the experimental part. It was tested in the Laboratory of Building Materials, FAST, VŠB - TUO in previous works [19-21]. In this mixture, a portion of the slag was replaced by fly ash in the proportions of 10,20 and $30 \%$.

Reference mixture:

\section{$450 \mathrm{~g}$ BFS}

$1350 \mathrm{~g}$ standardized sand

$100 \mathrm{~g} \mathrm{H}_{2} \mathrm{O}$

$127 \mathrm{ml}$ of activator $-\mathrm{SWG}$

\begin{tabular}{|c|c|c|c|c|c|c|c|c|}
\hline \multirow{2}{*}{$\begin{array}{l}\text { Mixed alkali - activated } \\
\text { materials activated by } \\
\text { sodium water glass with } \\
\text { silicate modulus } 2\end{array}$} & $\Rightarrow$ & $\begin{array}{l}\text { Alkali- } \\
\text { activated } \\
\text { binders }\end{array}$ & $\vec{\partial}$ & $\begin{array}{c}\text { Basic physical and } \\
\text { mechanical } \\
\text { properties }\end{array}$ & $\Rightarrow$ & $\begin{array}{c}\text { Resistance to frost and } \\
\text { aggressive } \\
\text { environments }\end{array}$ & & \\
\hline & $\Rightarrow$ & $\begin{array}{l}\text { Alkali- } \\
\text { activated } \\
\text { past }\end{array}$ & $\Rightarrow$ & $\begin{array}{l}\text { The course of } \\
\text { hydration in the } \\
\text { calorimeter }\end{array}$ & $\Rightarrow$ & $\begin{array}{l}\text { Determination of } \\
\text { thermal properties }\end{array}$ & $\Rightarrow$ & $\begin{array}{c}\text { Determination of } \\
\text { FTIR }\end{array}$ \\
\hline
\end{tabular}

\section{3- Results and Discussion}

\section{3-1-Determination of Amorphous Content in Fly Ash}

The percentage of amorphous phase in fly ash and chemical composition are shown in Tables 3 and 4. 
Table 3. Amorphous phase content of silica fly.

\begin{tabular}{cccccc}
\hline Sample & Element & $(\%)$ & Oxides & $(\%)$ & Percentage of amorphous phase (\%) \\
\hline \multirow{4}{*}{ FA } & $\mathrm{Al}$ & 10.81 & $\mathrm{Al}_{2} \mathrm{O}_{3}$ & 20.43 & \\
& $\mathrm{Si}$ & 18.68 & $\mathrm{Si}_{2} \mathrm{O}$ & 39.97 & 4.58 \\
& $\mathrm{~K}$ & 17.15 & $\mathrm{~K}_{2} \mathrm{O}$ & 20.71 & \\
& $\mathrm{Cl}$ & 0.55 & $\mathrm{Si}_{2} \mathrm{O}+\mathrm{Al}_{2} \mathrm{O}_{3}$ & 60.40 \\
\hline
\end{tabular}

Table 4. Amorphous phase content of fly ash after denitrification.

\begin{tabular}{cccccc}
\hline Sample & Element & $(\%)$ & Oxides & $(\%)$ & Percentage of amorphous phase (\%) \\
\hline \multirow{4}{*}{ FAD } & $\mathrm{Al}$ & 8.42 & $\mathrm{Al}_{2} \mathrm{O}_{3}$ & 15.91 & \\
& $\mathrm{Si}$ & 16.99 & $\mathrm{Si}_{2} \mathrm{O}$ & 36.38 & 4.17 \\
& $\mathrm{~K}$ & 16.32 & $\mathrm{~K}_{2} \mathrm{O}$ & 19.735 & \\
& $\mathrm{Cl}$ & 0.38 & $\mathrm{Si}_{2} \mathrm{O}+\mathrm{Al}_{2} \mathrm{O}_{3}$ & 52.29 \\
\hline
\end{tabular}

\section{3-2- Basic Physical - Mechanical Properties}

Strengths after 28 days of aging are shown in the Figures 1 and 2.

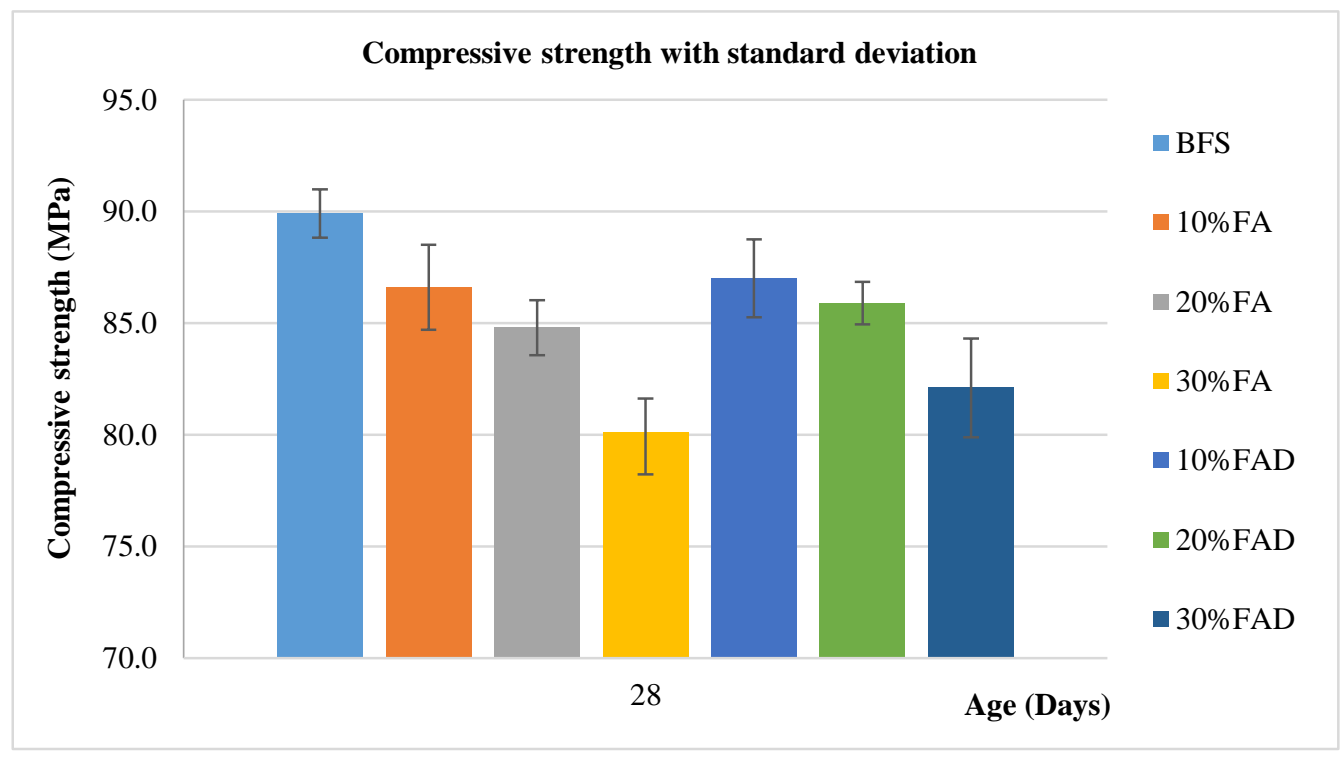

Figure 1. Compressive strength with standard deviation.

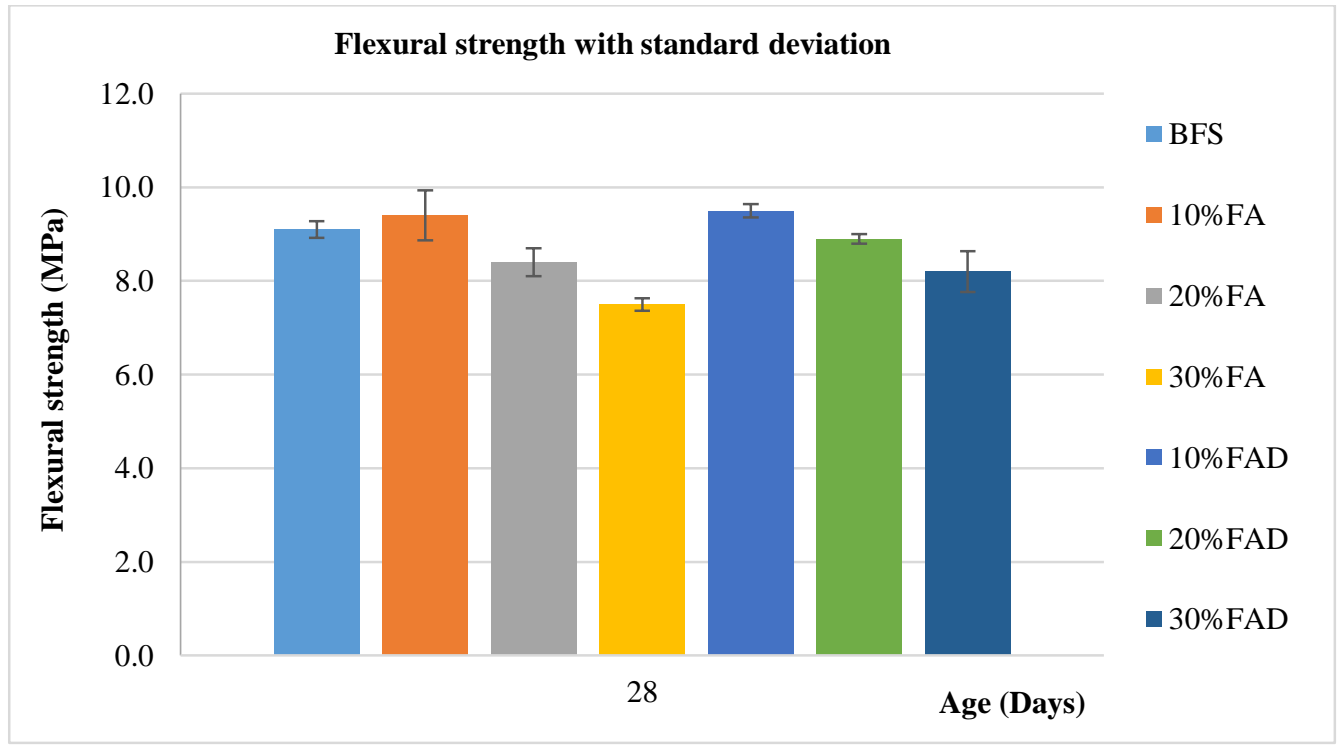

Figure 2. Flexural strength with standard deviation. 
The highest values of compressive strengths achieved the reference mixture, with increasing replacement of the slag with fly ash, the compressive strength gradually decreases. When comparing the effect of the denitrification process by the SNCR method on the strength values of the mixture with fly ash, no negative effects of the denitrification process on the resulting properties of the prepared recipes were found.

In the case of flexural strength, slightly higher strength achieved mixture with a $10 \%$ replacement of slag by fly ash. As the volume of the ash slag replacement increases, the strength decreases again. The initial assumption was that replacing $20 \%$ weight of the slag with fly ash would improve the mechanical properties. This assumption was only slightly reflected in the flexural strength of $10 \%$ slag replacement.

In Abdollahnejad et al. (2020) study [22], the authors report a flexural strength of alkali-activated sodium silicate slag after 28 days of maturation around $10 \mathrm{MPa}$. With increasing replacement of slag by fly ash, there are then significant decreases in strength. Compressive strengths of alkali-activated slag mixtures achieve around $100 \mathrm{MPa}$, and again, with increasing replacement of slag by fly ash, the strengths decrease. Authors followed the replacement of standardized sand with ceramic waste. These recipes achieved higher values for $10 \%$ slag replacement with fly ash. With a higher replacement of slag with fly ash, there was also a decrease in strength in these mixtures.

\section{3-3- Frost Resistance}

The values of compressive strength, flexural strength and frost resistance coefficients after 100 cycles are given in Table 5. Samples were placed in the freezer after 60 days of maturation.

Table 5. Frost resistance results.

\begin{tabular}{ccccccc}
\hline $\begin{array}{c}\text { OZN. } \\
\text { SWG }\end{array}$ & $\begin{array}{c}\text { Compressive } \\
\text { Strength Ref } \\
\text { (MPA) }\end{array}$ & $\begin{array}{c}\text { Compressive } \\
\text { Strength } \\
\text { Frost. (MPA) }\end{array}$ & $\begin{array}{c}\text { Coefficient of Frost } \\
\text { Resistance (-) }\end{array}$ & $\begin{array}{c}\text { Flexural Strength } \\
\text { Ref (MPA) }\end{array}$ & $\begin{array}{c}\text { Flexural Strength } \\
\text { Frost. (MPA) }\end{array}$ & $\begin{array}{c}\text { Coefficient Of Frost } \\
\text { Resistance (-) }\end{array}$ \\
\hline BFS & $104.2 \pm 1.2$ & $101.2 \pm 2.1$ & 0.97 & $7.6 \pm 0.2$ & $11.6 \pm 0.2$ & 1.53 \\
$\mathbf{1 0 \%}$ FA & $101.2 \pm 1.6$ & $97.4 \pm 1.6$ & 0.96 & $7.6 \pm 0.3$ & $11.3 \pm 0.5$ & 1.49 \\
$\mathbf{2 0 \%}$ FA & $96.2 \pm 1.1$ & $92.3 \pm 1.4$ & 0.96 & $8.1 \pm 0.0$ & $10.5 \pm 0.1$ & 1.30 \\
$\mathbf{3 0 \%}$ FA & $95.0 \pm 1.2$ & $94.0 \pm 1.6$ & 0.99 & $7.9 \pm 0.0$ & $9.2 \pm 0.3$ & 1.16 \\
$\mathbf{1 0 \%}$ FAD & $96.5 \pm 1.1$ & $94.3 \pm 2.0$ & 0.98 & $7.2 \pm 0.2$ & $10.5 \pm 0.3$ & 1.46 \\
$\mathbf{2 0 \%}$ FAD & $93.3 \pm 1.1$ & $92.5 \pm 2.6$ & 0.99 & $8.2 \pm 0.1$ & $11.7 \pm 0.3$ & 1.43 \\
$\mathbf{3 0 \%}$ FAD & $95.7 \pm 1.0$ & $92.7 \pm 1.6$ & 0.97 & $8.1 \pm 0.1$ & $10.5 \pm 0.1$ & 1.30 \\
\hline
\end{tabular}

The results of the frost resistance of alkali-activated materials are interesting mainly due to the significant increase of flexural strength of the samples after 100 freezing cycles, when this increase compared to the reference series was $50 \%$. On the other hand, for compressive strengths, the resulting differences between the reference series and the series after 100 freezing cycles were only in MPa units, corresponding to the standard deviations. In the future, research will focus on identifying the possible cause of a significant increase in flexural strength after the freezing process.

Shahrajabian and Behfarnia (2018) [23] tested the frost resistance of alkali-activated concretes on cubes of 100x100x100 mm. Blast furnace granulated slag was activated with sodium hydroxide and sodium silicate in a ratio of 3/1. The authors studied the effect of frost resistance after 90 days of maturation for 100, 200 and 300 cycles. The strengths after 90 days of maturation were around $45 \mathrm{MPa}$. Slight decrease in compressive strengths was detected for the mixtures, with a decrease of $6.14 \%$ for the reference mixture after 300 cycles. Authors primarily studied the effect of nano admixtures on the properties of alkali-activated materials.

\section{3-4-Influence of Leaching in Demineralized Water}

The values of compressive strength, flexural strength and demineralized water influence coefficients for 28 days are given in Table 6. Samples were placed in demineralized water after 60 days of maturation. The change of $\mathrm{pH}$ after 28 days of leaching is shown in the Table $7 . \mathrm{pH}$ of the original demineralized water was 6.5 . 
Table 6. Influence of leaching in demineralized water.

\begin{tabular}{|c|c|c|c|c|c|c|}
\hline $\begin{array}{l}\text { OZN. } \\
\text { SWG }\end{array}$ & $\begin{array}{c}\text { Compressive } \\
\text { Strength } \\
\text { Reference (MPA) } \\
\end{array}$ & $\begin{array}{l}\text { Compressive Strength } \\
\text { Demineralised (MPA) }\end{array}$ & $\begin{array}{l}\text { Coefficient of } \\
\text { Resistance (-) }\end{array}$ & $\begin{array}{l}\text { Flexural Strength } \\
\text { Reference (MPA) }\end{array}$ & $\begin{array}{c}\text { Flexural Strength } \\
\text { Demineralised (MPA) }\end{array}$ & $\begin{array}{l}\text { Coefficient of } \\
\text { Resistance (-) }\end{array}$ \\
\hline BFS & $104.2 \pm 1.2$ & $105.1 \pm 2.2$ & 1.01 & $7.6 \pm 0.2$ & $6.4 \pm 0.3$ & 0.84 \\
\hline $10 \%$ FA & $101.2 \pm 1.6$ & $101.0 \pm 0.8$ & 1.00 & $7.6 \pm 0.3$ & $6.1 \pm 0.2$ & 0.80 \\
\hline $20 \%$ FA & $96.2 \pm 1.1$ & $98.4 \pm 1.9$ & 1.02 & $8.1 \pm 0.0$ & $6.5 \pm 0.1$ & 0.80 \\
\hline $30 \%$ FA & $95.0 \pm 1.2$ & $96.9 \pm 1.1$ & 1.02 & $7.9 \pm 0.0$ & $7.2 \pm 0.3$ & 0.91 \\
\hline $10 \%$ FAD & $96.5 \pm 1.1$ & $98.6 \pm 1.2$ & 1.02 & $7.2 \pm 0.2$ & $6.1 \pm 0.1$ & 0.85 \\
\hline $20 \%$ FAD & $93.3 \pm 1.1$ & $98.5 \pm 1.0$ & 1.06 & $8.2 \pm 0.1$ & $6.6 \pm 0.2$ & 0.80 \\
\hline $30 \%$ FAD & $95.7 \pm 1.0$ & $97.0 \pm 1.7$ & 1.01 & $8.1 \pm 0.1$ & $7.8 \pm 0.6$ & 0.96 \\
\hline
\end{tabular}

In determining the resistance to demineralised water, the resulting compressive strengths of comparable values were obtained as for the reference series as for the tested series, which was for 28 days immersed in demineralised water. The differences were only in the order of standard deviations. Flexural strengths of tested samples in demineralised water decreased of $20 \%$.

It is interesting that the observed properties such as frost resistance and resistance to demineralised water affect only the flexural strength, not the compressive strength.

Table 7. Change of pH.

\begin{tabular}{cc}
\hline \multicolumn{2}{c}{ SWG } \\
\hline MARK & pH \\
\hline BFS & 12.89 \\
10\% FA & 12.84 \\
20\% FA & 12.75 \\
30\% FA & 12.66 \\
10\% FAD & 12.85 \\
20\% FAD & 12.74 \\
30\% FAD & 12.68 \\
\hline
\end{tabular}

\section{4- Fourier Transform Infrared Spectroscopy (FTIR)}

The Fourier transform infrared spectroscopy (FTIR) of the prepared mixtures were determined on a Nicolet iS50 FT-IR. FTIR tests were performed on samples that were used for calorimetry. Only binder components without aggregates were used. The ratio between binder, activator and water was determined according to the normal curing test of cement slurry, namely $500 \mathrm{~g}$ blast furnace slag, $141 \mathrm{ml}$ activator and $35 \mathrm{~g} \mathrm{H}_{2} \mathrm{O}$. The FTIR results are shown in Figures 3 to 6 .

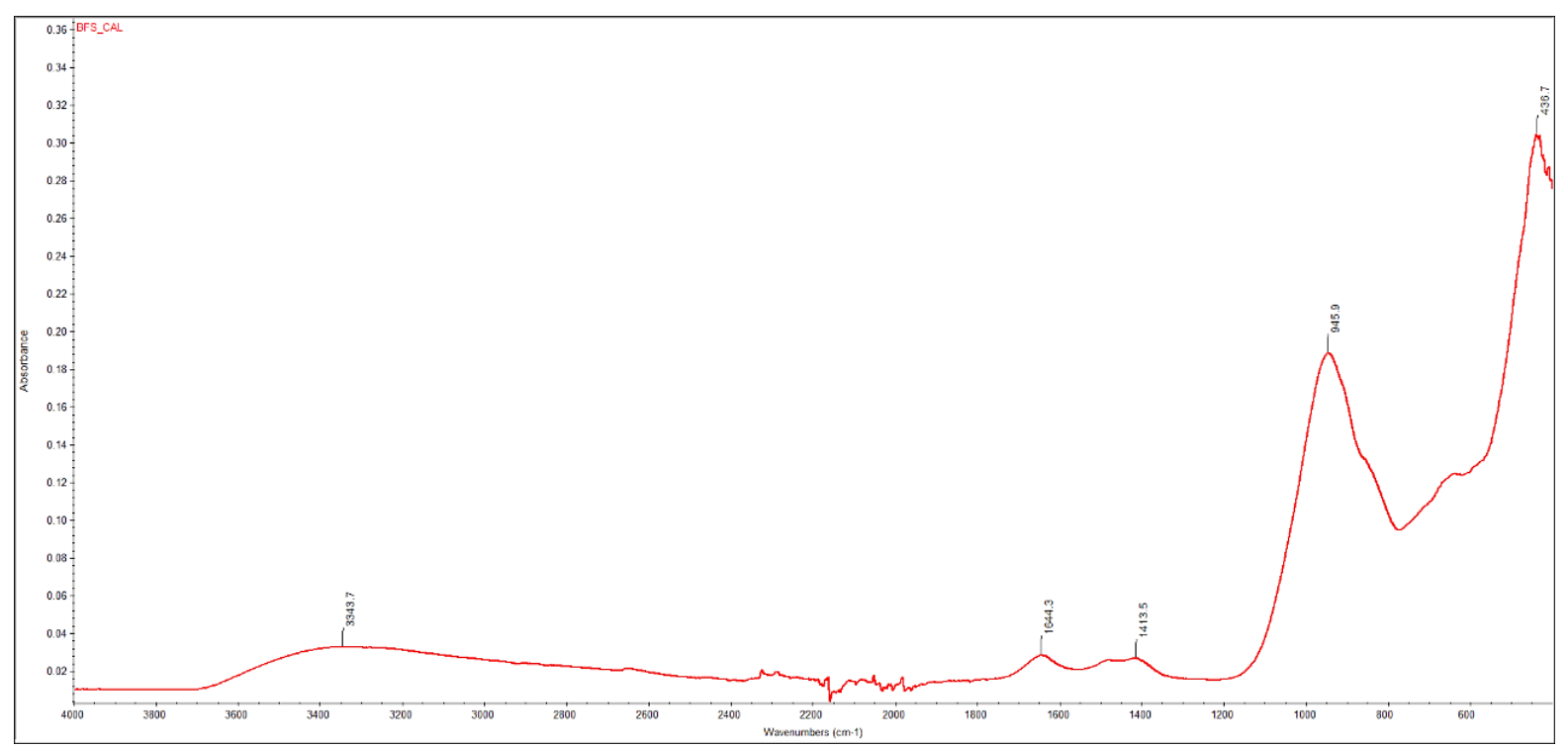

Figure 3. The result of FTIR using $100 \%$ BFS. 
Emerging Science Journal | Vol. 4, No. 6
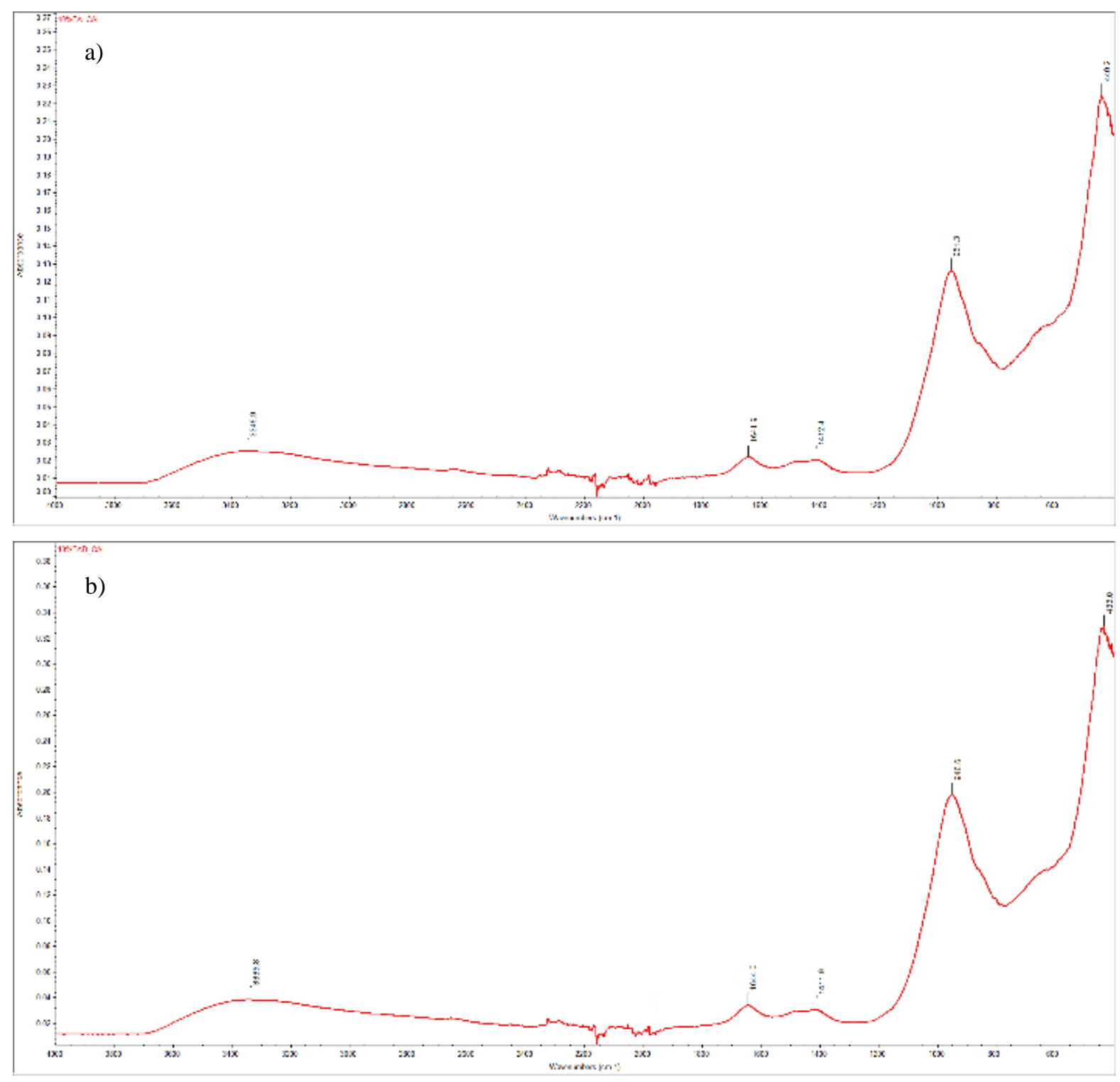

Figure 4. The result of FTIR using a) $10 \%$ FA b) $10 \%$ FAD.

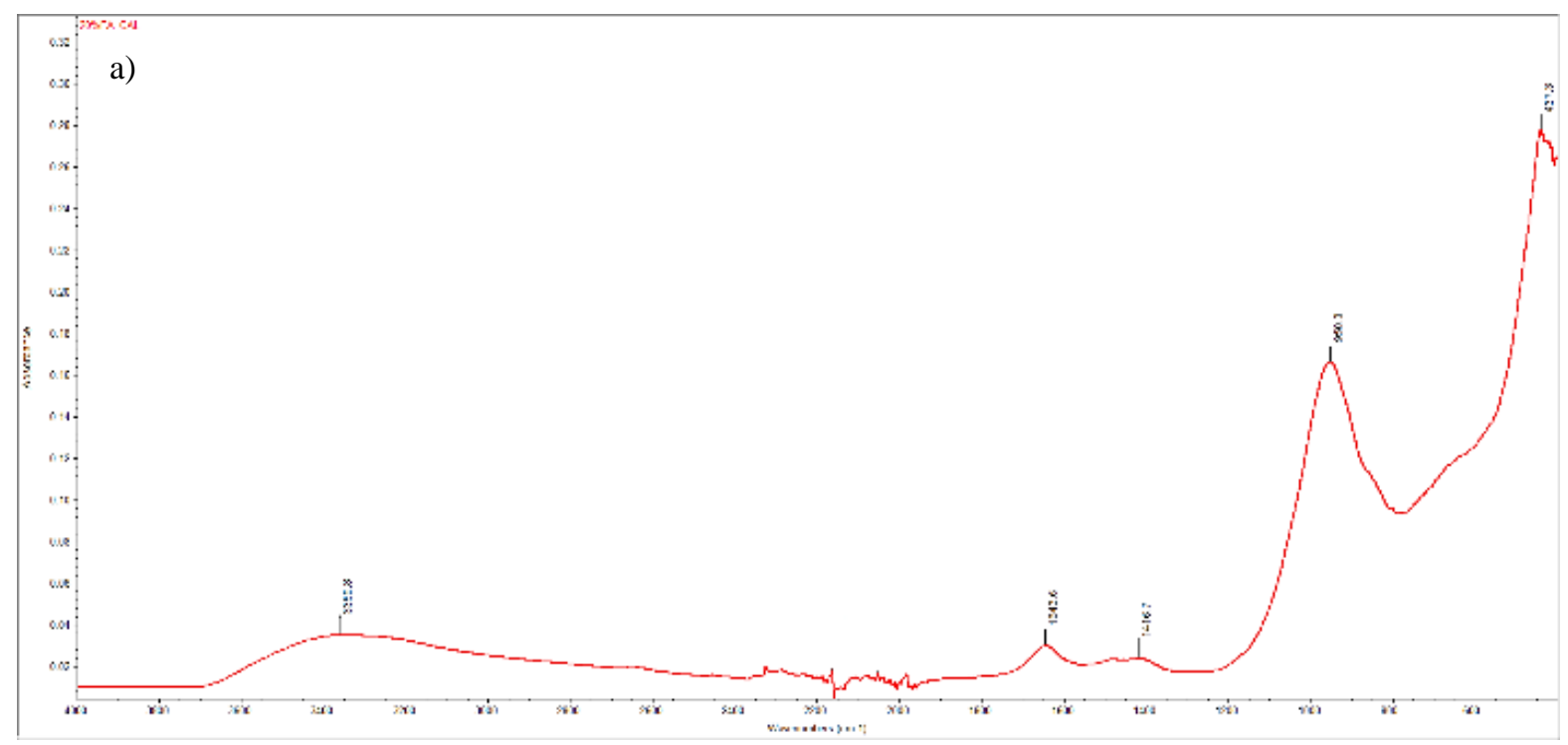

Page $\mid 499$ 


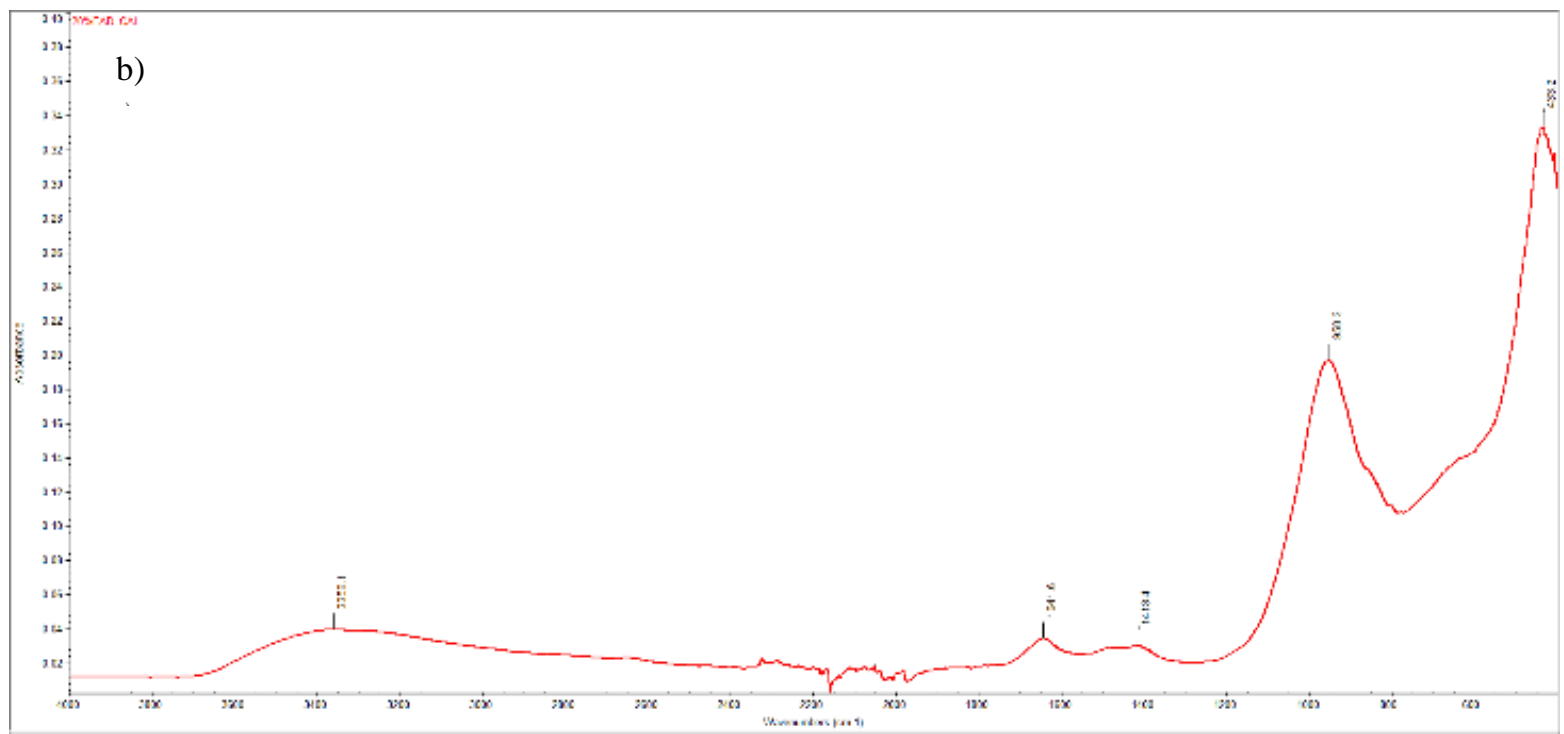

Figure 5. The result of FTIR using a) $20 \%$ FA b) $20 \%$ FAD.
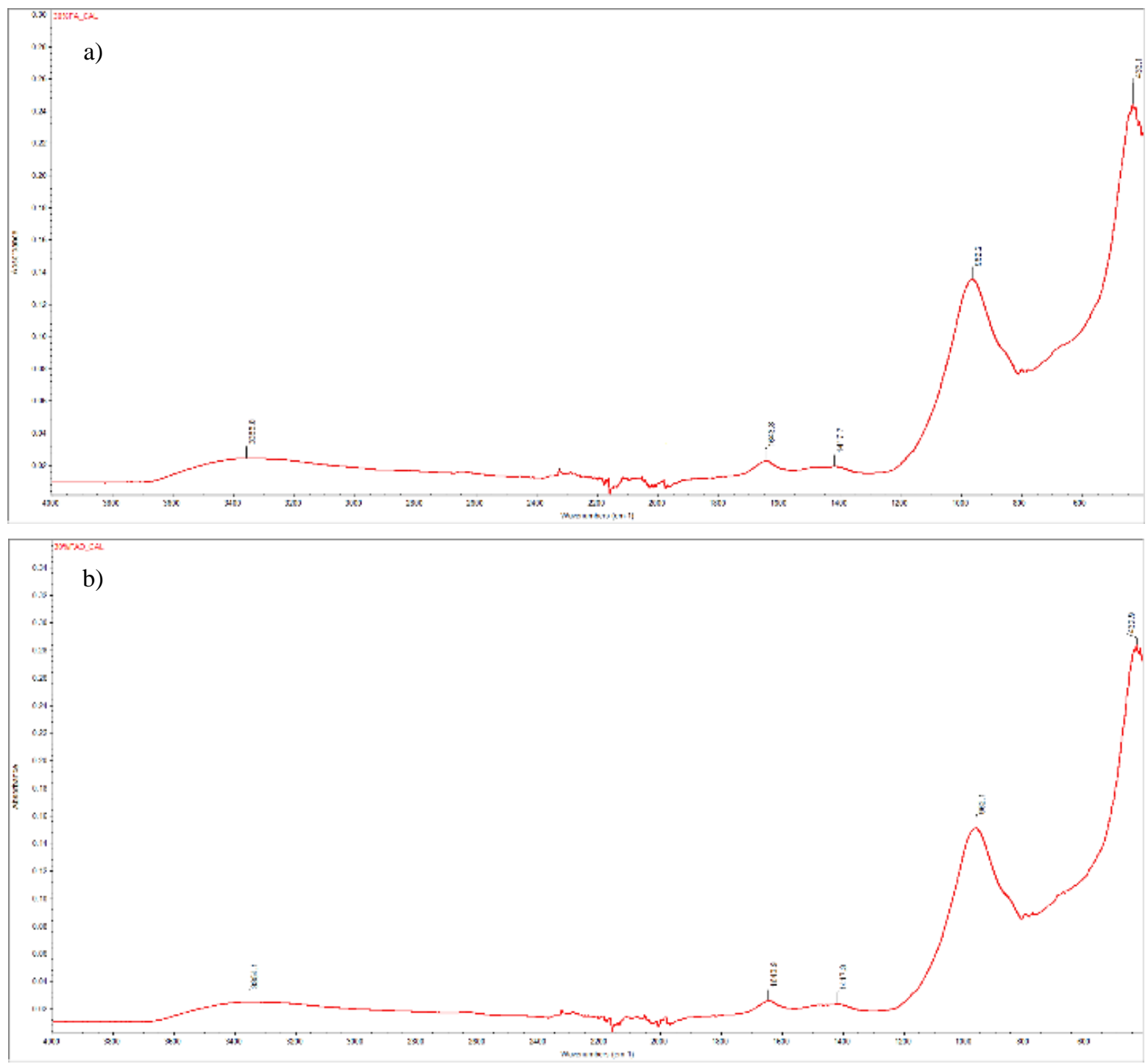

Figure 6. The result of FTIR using a) $30 \%$ FA b) $30 \%$ FAD

In the area of 3340 and $1640 \mathrm{~cm}^{-1}$, water stress $(\mathrm{O}-\mathrm{H})$ and deformation $(\mathrm{H}-\mathrm{OH})$ bands. These areas are caused by the presence of chemically bounded water in hydrated alkali-activated paste in different spectra. Very low intensity absorptions occur in the spectra of alkali-activated pastes around $3640 \mathrm{~cm}^{-1}$, which can be attributed to vibrations $\mathrm{OH}$ 
groups, $\mathrm{Ca}(\mathrm{OH})_{2}$. Absorption bands around $1410 \mathrm{~cm}^{-1}$, and between 870 and $710 \mathrm{~cm}^{-1}$ correspond to O-C-O vibrations in carbonates. The main absorption band of the reaction products is located at around at $945-950 \mathrm{~cm}^{-1}$ in all mixtures, which is assigned to the asymmetric stretching vibration of $\mathrm{Si}-\mathrm{O}-\mathrm{T}(\mathrm{T}=$ tetrahedral $\mathrm{Si}$ or $\mathrm{Al}$ ) terminal (non-bridging) bonds, indicating that the main reaction product is a chain structured $\mathrm{C}-(\mathrm{A})-\mathrm{S}-\mathrm{H}$ type gel. The area moving around $436 \mathrm{~cm}^{-1}$ represents bonds ( $\mathrm{Si}-\mathrm{O}-\mathrm{Si}$ and $\left.\mathrm{O}-\mathrm{Si}-\mathrm{O}\right)$ [2, 3, 24-27].

The main hydration product in the range of $945-950 \mathrm{~cm}^{-1}$ corresponds to both the C-(A)-S-H gel, which is formed by hydration of blast furnace slag, and to combined mixtures of the alkaline activation product N-A-S-H gel, for which fly ash-associated geopolymeric bonds are responsible. In alkali-activated materials, which are based only on blast furnace granulated slag or only on fly ash, these products are usually in the range of $950-1100 \mathrm{~cm}^{-1}[2,27]$. For mixtures with $30 \%$ fly ash, a slight peak was detected in the region of $797 \mathrm{~cm}^{-1}$, which represents Si-O-Si stretching bonds [26].

\section{5- Conclusion}

Within the compressive strength, the highest values achieved the reference mixture (BFS). With increasing dose of fly ash, the compressive strength slightly decrease. Slightly higher strengths achieved fly ash after denitrification by SNCR. The highest flexural strength after 28 days achieved mixture with $10 \%$ replacement of blast furnace slag by fly ash. As the fly ash dose increased, the strengths dropped below the reference mixture (BFS).

In the frost resistance determination, only minimal strength decreases were found within the standard deviations for compressive strength. The flexural strength after 100 cycles showed a significant increase in strength. For the reference mixtures (BFS), this increase was about 50\%. In the determination of resistance to demineralised water, only a minimum increase in strength within standard deviations was detected for compressive strength. In the case of flexural strength, a maximum reduction of $20 \%$ was observed. The lowest decreases were achieved in samples with $30 \%$ replacement of blast furnace slag by fly ash.

When measuring the $\mathrm{pH}$ of demineralized water after 28 days of leaching, the highest $\mathrm{pH}$ was measured at the reference mixture (BFS). As the fly ash dose increased, the $\mathrm{pH}$ decreased. Fly ash does not influence compressive strength during durability properties testing. Flexural strength increase of fly ash was not found as in the reference mixture (BFS), but in any case, increases were observed on frost resistance where fly ash had a positive effect. For flexural strength in the determination of resistance to demineralised water, the lowest decreases were found in the mixtures with $30 \%$ fly ash, while the highest decreases were found in mixtures of $20 \%$ fly ash and $10 \%$ FA.

As the strengths of the prepared mixtures did not drop by more than $25 \%$, therefore all mixtures can be described as resistant to frost and demineralised water. As a result, it is possible to use fly ash after denitrification by SNCR as an additive to alkaline activated materials. Within the FTIR analysis, there are only minimal differences for all mixtures in the monitored parameter.

\section{6- Funding}

This paper was financially supported by SGS SP2020/140 project of Faculty of Civil Engineering of VSB - TU in Ostrava.

\section{7- Conflict of Interest}

The author declares that there is no conflict of interests regarding the publication of this manuscript. In addition, the ethical issues, including plagiarism, informed consent, misconduct, data fabrication and/or falsification, double publication and/or submission, and redundancies have been completely observed by the authors.

\section{8- References}

[1] Abdollahnejad, Z., M. Mastali, B. Woof, and M. Illikainen. "High Strength Fiber Reinforced One-Part Alkali Activated Slag/fly Ash Binders with Ceramic Aggregates: Microscopic Analysis, Mechanical Properties, Drying Shrinkage, and Freeze-Thaw Resistance." Construction and Building Materials 241 (April 2020): 118129. doi:10.1016/j.conbuildmat.2020.118129.

[2] Ismail, Idawati, Susan A. Bernal, John L. Provis, Rackel San Nicolas, Sinin Hamdan, and Jannie S.J. van Deventer. "Modification of Phase Evolution in Alkali-Activated Blast Furnace Slag by the Incorporation of Fly Ash." Cement and Concrete Composites 45 (January 2014): 125-135. doi:10.1016/j.cemconcomp.2013.09.006.

[3] Gao, X., Q.L. Yu, and H.J.H. Brouwers. "Properties of Alkali Activated Slag-fly Ash Blends with Limestone Addition." Cement and Concrete Composites 59 (May 2015): 119-128. doi:10.1016/j.cemconcomp.2015.01.007.

[4] Oh, Jae Eun, Paulo J.M. Monteiro, Ssang Sun Jun, Sejin Choi, and Simon M. Clark. "The Evolution of Strength and Crystalline Phases for Alkali-Activated Ground Blast Furnace Slag and Fly Ash-Based Geopolymers." Cement and Concrete Research 40, no. 2 (February 2010): 189-196. doi:10.1016/j.cemconres.2009.10.010. 
[5] Marjanović, N., M. Komljenović, Z. Baščarević, V. Nikolić, and R. Petrović. "Physical-mechanical and Microstructural Properties of Alkali-Activated Fly Ash-blast Furnace Slag Blends.” Ceramics International 41, no. 1 (January 2015): 14211435. doi:10.1016/j.ceramint.2014.09.075.

[6] Alcamand, Himad A., Paulo H.R. Borges, Flávio A. Silva, and Ana Carolina C. Trindade. "The Effect of Matrix Composition and Calcium Content on the Sulfate Durability of Metakaolin and Metakaolin/slag Alkali-Activated Mortars." Ceramics International 44, no. 5 (April 2018): 5037-5044. doi:10.1016/j.ceramint.2017.12.102.

[7] Wong, John Kok Hee, Sien Ti Kok, and Soon Yee Wong. "Fibers, Geopolymers, Nano and Alkali-Activated Materials for Deep Soil Mix Binders." Civil Engineering Journal 6, no. 4 (April 1, 2020): 830-847. doi:10.28991/cej-2020-03091511.

[8] Humad, Abeer M., Ankit Kothari, John L. Provis, and Andrzej Cwirzen. "The Effect of Blast Furnace Slag/Fly Ash Ratio on Setting, Strength, and Shrinkage of Alkali-Activated Pastes and Concretes.” Frontiers in Materials 6 (February 14, 2019). doi:10.3389/fmats.2019.00009.

[9] Ye, Hailong. "Nanoscale Attraction Between Calcium-Aluminosilicate-Hydrate and Mg-Al Layered Double Hydroxides in Alkali-Activated Slag." Materials Characterization 140 (June 2018): 95-102. doi:10.1016/j.matchar.2018.03.049.

[10] Ye, Hailong, Chuanqing Fu, and Guojun Yang. "Influence of Dolomite on the Properties and Microstructure of AlkaliActivated Slag with and Without Pulverized Fly Ash." Cement and Concrete Composites 103 (October 2019): $224-232$. doi:10.1016/j.cemconcomp.2019.05.011.

[11] J. Vlček. "Material utilization of slags from iron and steel metallurgy by the alkaline activation method." Habilitation thesis, FMMI VŠB-TUO (2008)

[12] "Kotouč production plant", Available online: www.kotouc.cz (accessed on June 2020).

[13] "OQEMA", Available online: http://www.eurosarm.cz (accessed on June 2020).

[14] ČSN EN 196-1. Methods of testing cement - Part 1: Determination of strength.

[15] ČSN EN 1008 Mixing water for concrete - Specification for sampling, testing and assessing the suitability of water, including water recovered from processes in the concrete industry, as mixing water for concrete.

[16] ČSN EN 196-3 Methods of testing cement - Part 3: Determination of setting times and soundness.

[17] ČSN 722452. Frost resistance test of mortar. Czech Standards Institute.

[18] L. Krajčová Study of pozzolanite and amorphous fraction of metakaolin depending on firing temperature, VŠB - TUO (2017).

[19] J. Boháčová Study of influence of different types of fillers on properties of geopolymer systems based on alkali activated slags, VŠB - TUO (2008).

[20] J. Koňařík Influence of activator on basic properties of alkali activated systems, VŠB - TUO (2014).

[21] Mec, Pavel, Jana Boháčová, and Stanislav Staněk. "Mechanical Properties of Alkali-Activated Material with Waste Aggregate According to Porosity.” Materials Science Forum 865 (August 2016): 53-56. doi:10.4028/www.scientific.net/msf.865.53.

[22] Abdollahnejad, Z., M. Mastali, B. Woof, and M. Illikainen. "High Strength Fiber Reinforced One-Part Alkali Activated Slag/fly Ash Binders with Ceramic Aggregates: Microscopic Analysis, Mechanical Properties, Drying Shrinkage, and FreezeThaw Resistance." Construction and Building Materials 241 (April 2020): 118129. doi:10.1016/j.conbuildmat.2020.118129.

[23] Shahrajabian, Fatemeh, and Kiachehr Behfarnia. "The Effects of Nano Particles on Freeze and Thaw Resistance of AlkaliActivated Slag Concrete." Construction and Building Materials $176 \quad$ (July 2018): 172-178. doi:10.1016/j.conbuildmat.2018.05.033.

[24] Puertas, F., and A. Fernández-Jiménez. "Mineralogical and Microstructural Characterisation of Alkali-Activated Fly Ash/slag Pastes." Cement and Concrete Composites 25, no. 3 (April 2003): 287-292. doi:10.1016/s0958-9465(02)00059-8.

[25] Mejía de Gutiérrez, R., R. A. Robayo, and M. Gordillo. "Natural Pozzolan-and Granulated Blast Furnace Slag-Based Binary Geopolymers.” Materiales de Construcción 66, no. 321 (January 18, 2016): e077. doi:10.3989/mc.2016.03615.

[26] Silva, Isabel, João P. Castro-Gomes, and António Albuquerque. "Effect of Immersion in Water Partially Alkali-Activated Materials Obtained of Tungsten Mine Waste Mud." Construction and Building Materials 35 (October 2012): 117-124. doi:10.1016/j.conbuildmat.2012.02.069.

[27] Ismail, Idawati, Susan A. Bernal, John L. Provis, Sinin Hamdan, and Jannie S. J. van Deventer. "Microstructural Changes in Alkali Activated Fly Ash/slag Geopolymers with Sulfate Exposure.” Materials and Structures 46, no. 3 (July 11, 2012): 361373. doi:10.1617/s11527-012-9906-2. 